\title{
A study of prevalence of lower genital tract infections in HIV positive females - a cross sectional study
}

\author{
Jaishree Bamniya*, Pooja Singh, Anuradha Deora, Mili Markan, Himanshu Shah
}

Department of Obstetrics and Gynecology, GCS Medical College, Ahmadabad, Gujarat, India

Received: 07 December 2016

Revised: 10 December 2016

Accepted: 31 January 2017

\section{*Correspondence:}

Dr. Jaishree Bamniya,

E-mail: jaishreeskumar@yahoo.in

Copyright: () the author(s), publisher and licensee Medip Academy. This is an open-access article distributed under the terms of the Creative Commons Attribution Non-Commercial License, which permits unrestricted non-commercial use, distribution, and reproduction in any medium, provided the original work is properly cited.

\begin{abstract}
Background: The aim and objectives of the study was to determine the prevalence of lower genital tract infection (LGTI) with Candida spp, Trichomonas vaginalis, Neisseria gonorrhoeae, Chlamydia trachomatis, and bacterial vaginosis among symptomatic and asymptomatic women HIV seropositive females and control group attending gynec clinic.

Methods: This cross-sectional descriptive study stratified by reported symptoms of vaginal discharge was carried out at STD Clinic, Zenana Hospital with approval from Hospital Ethics Committee and informed written consent from patients. 50 HIV seropositive women and 50 control patients were included in the study. All the patients under study were subjected to Grams staining of the vaginal smear, Pap smear and Colposcopy. HPV DNA testing was done in all HIV positive patients in control group only patients showing dyskaryotic changes on cytology were subjected to colposcopy. All HIV seropositive women were subjected to additional tests of CD 4 and CD 8 cell counts.

Results: Prevalence of lower genital tract infections was high in HIV positive women (36\%) as compared to HIV negative group (24\%). Prevalence was significantly higher in HIV positive patients with CD 4 cell count less than 200 per microlitre that is $77.77 \%$ with $\mathrm{P}$ value $(0.007)$ which is highly significant statistically. More prevalence of Herpes (38\%) Candidiasis (28\%), Trichomoniasis (28\%), followed by HPV (22\%) and Chlamydia (8\%). In control group, bacterial vaginosis is most common with co-infection with trichomoniasis.

Conclusions: In lower genital tract infections, vaginal eco-system is altered. It increases risk of infection by opportunistic pathogens when the host defences became impaired. HIV positive females showed more prevalence of Herpes (38\%) Candidiasis (28\%), Trichomoniasis (28\%), followed by HPV (22\%) and Chlamydia (8\%). In control group patients with bacterial vaginosis was most common along with co-infection with trichomoniasis. HIV positive females have more dyskaryotic changes on colposcopy especially in patients with HPV positive. So HPV test should be mandatory in HIV patients to diagnose Carcinoma cervix at its initial stages.
\end{abstract}

Keywords: Colposcopy, CD4 cell count, Gram stain, HIV, Lower genital tract infections

\section{INTRODUCTION}

Vagina has a dynamic ecosystem. Susceptibility to lower genital tract infections is due to several physiologic factors in reproductive-age women, including the condition of the epithelial lining of the lower genital tract, the menstrual-cycle phase, and changes associated with pregnancy and contraceptive use. ${ }^{1}$ Most of these lower genital tract infections are caused by sexually transmitted diseases, such as Chlamydia trachomatis and Neisseria gonorrhoea.

Other common LGTI are Candidiasis, Trichomoniasis, Herpes, HPV and Bacterial vaginosis. Women also bear a 
disproportionate burden of the adverse sequelae of these infections, such as pelvic inflammatory disease (PID), ectopic pregnancy, and chronic pelvic pain. In addition, recent studies have repeatedly shown an association between the presence of lower genital tract infections and increased acquisition and transmission of HIV. ${ }^{2}$

\section{METHODS}

This study was conducted in $50 \mathrm{HIV}$ positive and 50 control patients at STD Clinic Zenana hospital in collaboration with STD department of S.M.S Medical College.

\section{Inclusion criteria}

- Diagnosed cases of HIV

- Women in reproductive age group i.e. between 20-45

- Women with complaints of vaginal discharge, pain lower abdomen, burning, itching vulva, dyspareunia, backache

- Women having multiple sexual partners

\section{Exclusion criteria}

- Any patient with bleeding per vaginum

- Pregnant females

- Postmenopausal females

- Diagnosed cases of Carcinoma Cervix

- Patients having Prolapse Uterus

- Patients who have used vaginal pessary or douche in last 4-5 days

All the patients were subjected to detailed clinical history on predesigned proforma, Examination, Pap's smear, Grams smear of vagina, Colposcopy, HPV DNA testing, HIV ELISA and CD 4/CD8 ratio in HIV positive patients.

Candidiasis is diagnosed by microscopic detection of budding yeast or pseudohyphae in vaginal secretions. Method used for detection of Trichomonas vaginalis was culture. Bacterial vaginosis was diagnosed by Amsel criteria. At least three of the four criteria should be present for the diagnosis to be confirmed.

(1) Homogeneous adherent discharge

(2) Vaginal fluid $\mathrm{pH}$ greater than 4.5

(3) Amine odour

(4) Clue cells.

A diagnosis may also be made by detecting the replacement of lactobacilli by a mixed presumably anaerobic flora. This was accomplished by examining Gram stain of vaginal fluid. Herpes was clinical diagnosis and HPV diagnosed by HPV nucleic acid detection kit and that only in HIV positive patients as it is a costly test. Control group was not subjected to HPV test.

\section{RESULTS}

Maximum number of patients were in the age group of 21 to 30 years with $60 \%$ in HIV positive (Group A) and $44 \%$ in the control group (Group B). It shows that most of the women were sexually active.

Table 1: Distribution of cases according to age.

\begin{tabular}{|lllll|}
\hline \multirow{2}{*}{ Age (in yrs) } & \multicolumn{2}{l|}{$\begin{array}{l}\text { Group A } \\
\text { HIV positive } \\
\text { women }(\mathbf{n = 5 0})\end{array}$} & $\begin{array}{l}\text { Group B } \\
\text { Control group } \\
(\mathbf{n = 5 0})\end{array}$ \\
\hline & No. & $\%$ & No. & $\%$ \\
\hline$<20$ & 2 & 4 & 6 & 12 \\
\hline $21-30$ & 30 & 60 & 22 & 44 \\
\hline $31-40$ & 15 & 30 & 17 & 34 \\
\hline$>40$ & 3 & 6 & 5 & 10 \\
\hline Total & 50 & 100 & 50 & 100 \\
\hline
\end{tabular}

Table 2: Distribution of patients according to LGTI.

\begin{tabular}{|lllll|}
\hline LGTI & \multicolumn{2}{l}{$\begin{array}{l}\text { Group A } \\
\text { HIV positive } \\
\text { women }(\mathbf{n = 5 0})\end{array}$} & $\begin{array}{l}\text { Group B } \\
\text { Control group } \\
(\mathbf{n = 5 0 )}\end{array}$ \\
\hline & No. & $\%$ & No. & $\%$ \\
\hline Candidiasis & 15 & 30 & 10 & 20 \\
\hline $\begin{array}{l}\text { Human } \\
\text { pappiloma } \\
\text { virus }\end{array}$ & 11 & 22 & - & - \\
\hline Trichomoniasis & 14 & 28 & 12 & 24 \\
\hline $\begin{array}{l}\text { Bacterial } \\
\text { vaginosis }\end{array}$ & 18 & 36 & 12 & 24 \\
\hline Chlamydia & 4 & 8 & 5 & 10 \\
\hline Herpes & 19 & 38 & 1 & 2 \\
\hline
\end{tabular}

In our study it was found that in HIV positive group Herpes (38\%) was most prevalent infection followed by Candidiasis (30\%) and Trichomoniasis (28\%). In control group Trichomoniasis and Bacterial vaginosis was most prevalent $(28 \%)$. None of the patients in Control group were subjected to HPV testing.

Table 3: Distribution of patients according to cytology.

\begin{tabular}{|lllll|}
\hline $\begin{array}{l}\text { Cytology } \\
\text { findings }\end{array}$ & \multicolumn{2}{l}{$\begin{array}{l}\text { Group A } \\
\text { HIV positive } \\
\text { women }\end{array}$} & \multicolumn{2}{l|}{$\begin{array}{l}\text { Group B } \\
\text { Control group }\end{array}$} \\
& No. & $\%$ & No. & $\%$ \\
\hline $\mathbf{n}=50)$ & \\
\hline NAD & 12 & 24 & 19 & 38 \\
\hline Inflammatory & 29 & 58 & 28 & 56 \\
\hline $\begin{array}{l}\text { Koilocytic } \\
\text { and }\end{array}$ & 9 & 18 & 3 & 6 \\
$\begin{array}{l}\text { dyskaryotic } \\
\text { Total }\end{array}$ & 50 & 100 & 50 & 100 \\
\hline
\end{tabular}

The high prevalence of Koilocytosis and Dyskaryosis was probably due to high prevalence of HPV (22\%) 
infection in HIV positive group. In control group only 3 patients who showed dyskaryotic changes on cytology were subjected to colposcopy. Out of 3, one had Grade I changes and two cases had Grade II changes.

Table 4: Distribution of patients according to colposcopic findings.

\begin{tabular}{|lllll|}
\hline $\begin{array}{l}\text { Colposcopic } \\
\text { findings }\end{array}$ & $\begin{array}{l}\text { Group A } \\
\text { HIV positive } \\
\text { women }(\mathbf{n = 5 0})\end{array}$ & $\begin{array}{l}\text { Group B } \\
\text { Control group } \\
(\mathbf{n}=50)\end{array}$ \\
\hline NAD & No. & $\%$ & No. & $\%$ \\
\hline Grade I & 17 & 34 & - & 0 \\
\hline Grade II & 5 & 10 & 2 & 4 \\
\hline Grade III & 3 & 6 & - & \\
\hline Total & 50 & 100 & 3 & 6 \\
\hline
\end{tabular}

Table 5: Distribution of patients according to absolute CD4 cell count.

\begin{tabular}{|lll|}
\hline $\begin{array}{l}\text { A bsolute CD4 cell } \\
\text { count }\end{array}$ & $\begin{array}{l}\text { Group A } \\
(\mathbf{n = 5 0})\end{array}$ \\
\hline No. & $\%$ \\
\hline$>500$ & 7 & 14 \\
\hline $200-499$ & 18 & 36 \\
\hline$<200$ & 25 & 50 \\
\hline Total & 50 & 100 \\
\hline
\end{tabular}

\section{DISCUSSION}

In present study HIV positive patients showed more prevalence of Herpes (38\%) Candidiasis (28\%), Trichomoniasis (28\%), followed by HPV (22\%) and Chlamydia (8\%). In control group patients with bacterial vaginosis most common co-infection was of Trichomoniasis. This correlate well with study done in STD clinic in Seattle in which $75 \%$ of women with trichomoniasis also had bacterial vaginosis compared with $47 \%$ of women without trichomoniaisis $(\mathrm{P}<0.001) .^{3}$

Uvin C et al in his study found a prevalence of Trichomoniasis in $9.4 \%-29.5 \%$ of HIV positive and $8.2 \%-23.4 \%$ of HIV negative females. ${ }^{4}$

Helfgott A et al found that difference of frequency of prevalence of Trichomoniasis in HIV positive and HIV negative group was significant $(\mathrm{P}=0.015$, OR, 9.5; $95 \% \mathrm{CI}, 1.6 \%, 54.9 \%$ ). HPV was prevalent in $8.4 \%$ of HIV positive and $7.1 \%$ of HIV negative women. Study showed a high prevalence of Chlamydia in HIV negative $(\mathrm{P}=0.0001) .^{5}$

Riordan et al reported Candida albicans and bacterial vaginosis occurred in $22-26 \%$ of women with vaginal discharge. $72 \%$ of women with vaginal $\mathrm{pH} 4.5$ have trichomonas and/or clue cells compared with $15 \%$ of those with normal $\mathrm{pH}$. Cervicitis or cervical contact bleeding was associated with trichomonas. Candida, but not clue cells, was linked with vaginal inflammation. $\mathrm{N}$. gonorrhoea was isolated from 12 women $(2.4 \%), 10$ of whom has symptoms. ${ }^{6}$

Minkoff et al reported that HIV positive were 3.4 times more likely to have HPV infection as compared to general population $(\mathrm{P}<0.001,95 \% \mathrm{CI}, 3.13 \%-4.88 \%){ }^{7}$ Landers et al in a study of 598 women reported bacterial vaginosis in $276(46 \%)$, vaginal yeast (29\%), Trichomoniasis (12\%) and Chlamydia (11\%).The most prevalent co-infection was Bacterial vaginosis with Trichomoniasis. ${ }^{8}$ In present study in both groups cytology showed inflammatory smear in maximum no. of cases i.e. HIV positive (58\%) and control group (54\%). 7 patients (14\%) in HIV positive and 3 cases $(6 \%)$ in control group had koilocytosis and dyskaryotic changes.

Alison et al reported HIV-infected women are significantly more likely than HIV-uninfected women to have incident and persistent HPV cervical infections and to develop incident precancers such as squamous intraepithelial lesions (SIL) including high-grade SIL (HSIL). Among HIV-infected women, the incidence of HPV infection and SIL increases with lower CD4 ${ }^{+}$T-cell count (CD4). This high prevalence was probably due to high prevalence of HPV (22.22\%) infection in HIV positive female. ${ }^{9}$

Measurement of vaginal $\mathrm{pH}$ in the clinic is the single most useful clinical finding for directing empirical therapy. These results suggest that women with high $\mathrm{pH}$ could be given metronidazole before laboratory confirmation; that bacterial infection can be diagnosed by vaginal discharge, high $\mathrm{pH}$ and clue cells; that cervical swabs are more accurate than vaginal swabs for determining trichomonas; and that cervical smears for cytology are equally good for trichomonas; and that the high prevalence of gonococci justifies use of a culture medium that will also support growth of Candida. ${ }^{10}$

\section{CONCLUSION}

In lower genital tract infections, vaginal eco-system is altered. It increases risk of infection by opportunistic pathogens when the host defences becomes impaired.

Measurement of vaginal $\mathrm{pH}$ in the clinic is the single most useful clinical finding for directing empirical therapy. These results suggest that women with high $\mathrm{pH}$ could be given metronidazole before laboratory confirmation; that bacterial infection can be diagnosed by vaginal discharge, high $\mathrm{pH}$ and clue cells; that cervical swabs are more accurate than vaginal swabs for determining trichomonas; and that cervical smears for cytology are equally good for trichomonas. ${ }^{10}$

HIV positive females showed more prevalence of Herpes (38\%) Candidiasis (28\%), Trichomoniasis (28\%), followed by HPV (22\%) and Chlamydia (8\%). In control group patients bacterial vaginosis was most common 
along with co- infection with Trichomoniasis. HIV positive females have more dyskaryotic changes on colposcopy especially in patients with HPV positive. So HPV test should be mandatory in HIV patients to diagnose Carcinoma cervix at its initial stages. All LGTIs should be promptly treated to reduce the burden of complications due to these infections.

Funding: No funding sources

Conflict of interest: None declared

Ethical approval: The study was approved by the Institutional Ethics Committee

\section{REFERENCES}

1. Bolan G, Ehrhardt AA, Wasserheit J. Gender perspectives and STDs. In Sexually Transmitted Diseases ed. 3. Edited by Holmes KK, Sparling PF, Mårdh PA, et al. New York: McGraw-Hill; 1999:117-127.

2. Fleming DT, Wasserheit JN. From epidemiological synergy to public health policy and practice: the contribution of other sexually transmitted diseases to sexual transmission of HIV infection. Sex Transm Infect. 1999;75:3-17.

3. Wolner-Hanssen P, Krieger JN, Stevens CE, Kiviat NB, Koutsky L, Critchow C. Clinical manifestation of vaginal trichomoniasis. JAMA. 1989;261:571-6.

4. Cu- Uvin S, Ko H, Jamieson DJ, Hogan JW, Schuman P, Anderson J. HIV Epidemiology Research study Group. Prevalence, incidence and persistence or recurrence of trichomoniasis among HIV positive women and among HIV negative women at risk for HIV infection. Clin Infect Dis. 2002;34(10):1406-11.

5. Helfgott A, Eriksen N, Bundrik M. Vaginal infections in human immunodeficiency virus infected women. Am J Obstet Gynecol. 2000;183:347-55.

6. Riordan T, Macaulay ME, James JM, Leventhall PA, Morris EM, Neal BR. A prospective study of genital infections in a family-planning clinic. Microbiological findings and their association with vaginal symptoms. Epidemiol Infect. 1990;104(1):47-53.

7. Minkoff, Feldman J, Howard D, Strickler D. Relationship between smoking and Human Pappiloma virus Infection in HIV infected and uninfected women. J Infect Dis. 2004;189:1821-8.

8. Landers D, WisenfeldC, Heine P. Predictive value of the clinical diagnosis of lower genital tract infection in women. Am J Obstet Gynecol. 2004;190:1004-10.

9. Abraham AG, Jing Y, D'Souza G, Gange SJ. Invasive Cervical Cancer Risk Among HIV-infected Women A North American Multicohort Collaboration Prospective Study. J Acquir Immune Defic Syndr. 2013;62(4):405-13.

10. Anh PK, Khanh NT, Ha DT, Chien DT, Thuc PT, Luong PH, et al. Prevalence of lower genital tract infection among women attending maternal and child health and family planning clinics in Hanoi, Vietnam. Southeast Asian J Trop Med Public Health. 2003;34(2):367-73.

Cite this article as: Bamniya $\mathrm{J}$, Singh $\mathrm{P}$, Deora A, Markan M, Shah H. A study of prevalence of lower genital tract infections in HIV positive females - a cross sectional study. Int J Reprod Contracept Obstet Gynecol 2017;6:645-8. 